\title{
Post-2015와 불평등 해소의 과제: 인권적 접근
}

\section{이주영(서울대 인권센터 전문위원)}

목 차

들어가며

I. 불평등과 빈곤

1. 불평등의 다면적 양상

2. 불평등을 증가시키는 요인

3. 불평등이 야기하는 사회적 효과

II. 불평등과 인권

1. 개발에 대한 인권적 접근

2. 차별금지와 평등: 국제인권규범의 기초

3. '실질적 평등'의 내용

III. Post-2015 지속가능 발전의 기초로서의 인권과 평등

1. 불평등 완화, 평등 증진을 위한 정책의 방향성

2. Post-2015 지속가능 발전목표(SDG)를 통한 평등의 증진 나가며

\section{들어가며}

전 세계적으로 지난 2-30여 년간 물질적 부의 성장은 눈부시다. 1990년 이후 저 소득국가와 중소득국가의 GDP가 두 배 이상 증가하였고 개발도상국 내 기대수명도 63.2세에서 68.6세로 늘었다. 하지만 다수의 시민들이 성장의 혜택에서 체계적으로 배제되고 부유한 계층이 그 혜택을 지배하는 불평등 현상이 지속 혹은 증가하고 있 다. 2015 년 1 월에 열린 다보스 포럼에서는 전 세계 상위 $1 \%$ 의 사람들이 소유하고 있 
는 전 세계 자산(소득 제외)의 비율이 2009년 44\%에서 2014년 48\%로 늘었고, 관련 된 정책의 변화가 없다면, 2016년에는 그 비율이 $50 \%$ 를 넘길 것이라는 분석1)이 발 표되었다(Oxfam, 2015, p.2). 여전히 12 억이 넘는 사람들이 하루 1.25 달러 소득 이 하의 극빈상태로 살아가고 있는 참혹한 현실과 극명히 대조된다(UNDP, 2013, p.1). 2000년 전 세계 189 개국 지도자들은 새천년선언(Millennium Declaration)을 채택하 면서 '우리는 인간존엄, 평등, 형평의 원칙을 글로벌 차원에서 옹호해야 할 공동의 책임이 있다. (세계의) 지도자로서 우리는 세계 모든 사람들, 특히 가장 취약한 위치 에 있는 사람들, 그리고 미래가 달려 있는 전 세계의 어린이들에 대한 의무를 지고 있다.'고 약속하였다. 인권과 평등, 형평 증진의 약속이 새천년개발목표(Millennium Development Goals: 이하 MDGs)에서는 소홀히 다루어졌다. 2015년 9월에 채택될 글로벌 개발의제에서는 인권과 평등, 형평 증진이라는 국제사회의 약속이 현실이 되 도록 하는 것이 오늘날의 우리의 과제이다.

본 논문의 제 1 장은 불평등은 소득, 건강, 교육 등 다양한 측면에서 나타나고 있으 며, 젠더, 민족·인종, 장애, 지역 등에 근거한 차별과 중첩되어 불평등이 심화되는 양상을 띠고 있는 현실로부터 출발해서, 불평등의 증가는 자연적인 것이 아니라 국 제적 차원의 사회경제적 변동과 국내적 차원의 경제, 사회 분야의 정책 등의 결과이 며, 자신이 통제할 수 없는 조건들에 의해 기회가 불공평하게 제한되는 현실을 빚어 낼 뿐 아니라 빈곤을 퇴치하고 발전을 지속시키는 데도 저해 요인으로 작용한다는 연구결과들을 재조명한다. 제2장은 국제인권법 상의 원칙과 기준들을 바탕으로 하는 인권적 접근을 소개하고, 인권으로서 추구해야 할 실질적 평등의 의미를 탐색한다. 제 3 장에서는 불평등을 완화하고 소외계층의 인권을 증진하기 위해 필요한 정책적 과 제들을 검토하고, Post-2015 개발의제의 논의 과정에서 이러한 내용들이 어떻게 반 영되고 있는지를 살펴본다.

1) 이러한 분석은 스위스의 거대 금융회사인 Credit Suisse의 관련 데이터를 토대로 한 것이다. 


\section{I. 불평등과 빈곤}

\section{1. 불평등의 다면적 양상}

제 I장

오늘날 지구촌의 핵심 의제 중 하나는 불평등이다. 유엔 경제사회사무국(2013, p.29)에 따르면, 1990 년과 2012년 사이에 통계자료가 확보되는 130 개국 중 65 개국 에서 가용소득 간의 불평등이 증가하였고, 인구의 $2 / 3$ 이상이 이 65 개국에 살고 있 다. 즉, 전세계 인구의 $2 / 3$ 이상이 불평등이 점증하는 사회에 살고 있는 것이다. 또 한, 소득불평등의 감소추세가 보이는 나라들 중엔 애초에 불평등 때문에 아주 높았 었기 때문에 감소 추세라 하지만 여전히 높은 불평등 현상을 보이는 나라도 다수 있 다는 점을 유의해야 한다(UN Department of Economic and Social Affairs, 2013, p.29). 불평등은 소득뿐 아니라, 교육, 건강, 영양, 일자리, 정치적 참여 등 인권을 구성하는 다양한 측면에서의 격차로 나타난다(UNDP, 2013, pp.119-159). 불평등은 소득이나 자산을 중심으로 한 개인들 간의 격차(수직적 불평등)로도 나타나지만, 젠 더, 장애, 지역, 인종, 민족, 종교 등과 연관되어 특정 집단들에게 자원이나 기회의 배분이 불리하게 주어지고 결과에 있어 큰 격차로 나타나는 '수평적' 불평등도 많은 사회에서 관찰된다. 이를테면, 빈곤가정이나 농촌지역의 아동이 부유한 가정이나 도 시에 사는 아동에 비해 저체중일 확률이 훨씬 높고, 일부 최빈국에서는 소득 하위 계층에 속하는 아동이 상위 계층의 아동에 비해 초등학교를 다닐 확률이 3 배 낮으 며, 학교를 중도 이탈하는 아동 중 여아(女兒)가 남아(男兒)에 비해 횔씬 높다 (UNRISD, 2010, p.2).

아래 상자 안의 내용은 MDGs 상의 빈곤 지표들이 젠더, 지역, 인종, 민족 등과 중첩적으로 연관되어 불평등하게 나타나고 있음을 보여준다. 


\section{$\mathrm{MDG}$ 지표를 통해 본 그룹 간 인간 개발 격차 \\ (Kabeer, 2010; Melamed and Samman 2013 참조)}

라틴 아메리카

- 에콰도르에서는 100,000 명 출생 당 모성사망률이 전국 평균 74 명인 반면, 오지에 사는 선주민들에게서는 250명으로 훨씬 높게 나타났다(2003년).

- 멕시코의 게레로 주의 모성사망률은 100,000 명 출생 당 128 명으로, 북부 레 온 주의 모성사망률(100,000명 출생 당 27명)의 5배에 근접한다(2005년).

- 페루의 경우, 청년들을 대상으로 조사했을 때 평균 취학 연수가 10 년이 조 금 못 미치는 한편, 저소득 선주민 여성들의 경우 그 기간이 5년으로 훨 씬 짧았다.

- 브라질에서는 소득분포 하위 $10 \%$ 에 속하는 가구 중 아프리카계가 $74 \%$ 를 차지한다(2005년).

\section{아시아}

- 중국의 부유한 동부 지방에서는 저체중아동의 비율이 $5.8 \%$ 로, 상대적으로 가난한 서부지방(12.5\%)의 절반 이하이다(2005년).

- 중국에서 전체인구 중 $10 \%$ 도 되지 않는 소수민족이 중국 내 극빈층의 $46 \%$ 를 차지한다(2003년).

- 네팔에서 달릿 안에서는 5 세 미만 사망률이 1,000 명 출생 당 90 명으로 네와르 카스트(1,000명 당 43명)에 비해 두 배 이상 된다(2006년).

- 베트남의 경우, 소수민족의 $7 \%$ 만이 개량 화장실을 이용할 수 있는 한편, 주류인 킨족과 중국계는 그 수치가 43\%이다(2006년).

\section{아프리카}

- 나이지리아의 남서부 지역 아동사망률은 1,000 명 출생 당 32 명인 반면, 북서부 지역은 139명이다(2008년).

- 남아프리카 공화국 내 흑인들의 소득은 백인 소득의 $13 \%$ 수준에 불과하다 (2008년).

- 케냐에서 훈련된 조산원의 도움을 받아 출산하는 여성의 비율이 미지켄다 족에서는 $27 \%$ 이고, 키쿠유족에서는 $71 \%$ 로 큰 격차를 보인다(1998년). 
각 나라, 지역마다 차이가 있지만, 소득과 더불어, 인종, 민족, 카스트, 언어, 종교, 거주지역 등으로 표현되는 그룹정체성이 중첩적으로 결합해 불평등의 배경을 형성하 는 경우가 많다(UNRISD, 2010, pp.81-106; Kabeer, 2010, p.13). 다민족 사회에서 는 지역 간 불평등과 민족 간 불평등이 밀접하게 관련성을 보이는 것이 일반적이지 만, 하나의 민족이 여러 지역에 흩어져 사는 경우도 있기 때문에 불평등의 양상이 늘 이런 전형성을 띠는 것은 아니다(UNRISD, 2010, p.13). 젠더는 인종, 민족, 카스트, 언어, 종교, 장애, 거주지역 등의 다른 집단적 요인과 중첩되어, 여성과 여아가 각 집 단들 내에서도 더 열악한 삶의 위치를 차지하는 현실을 빚어낸다(Kabeer, 2010, $\mathrm{p} .13)$. 정치인 중 여성비율이 현저히 낮은 점, 고용 및 직종에서의 불평등, 상당히 많 은 지역에서 여전히 여아(女兒)의 중등교육 진학률이 남아(男兒)보다 더 낮은 점, 모 성사망률 감소 분야에서 가장 성과가 낮다는 점 등 $\mathrm{MDGs}$ 와 관련한 평가는 젠더를 기반으로 한 차별적 삶의 현실을 여실히 드러낸다(UN System Task Team on the Post-2015 UN Development Agenda, 이하 UN System Task Team, 2012a, p.4).

\section{2. 불평등을 증가시키는 요인}

점증하는 소득불평등은 경제세계화라는 외적 요인과 그와 연관된 국내의 사회경제 정책이 주요한 배경으로 분석되고 있다(UNRISD, 2010, p.59; UNDP, 2013, pp. 72-75). 1980년대 이후, 많은 나라들에서 소득불평등이 증가하는 경향이 관찰되는 데, 세계적인 차원의 금융 자유화와 이에 결부된 숙련노동 우대 경향이 소득불평등 을 증가시키는 경향을 나타냈다고 분석된다(UNDP, 2013, pp.72-83). ${ }^{2)}$ 이러한 외적 요인과 연동되어 국내의 정책이 소득불평등의 가속화에 영향을 미쳤는데, 성장보다 가격안정을 중시하는 통화정책, 노동자의 권리를 약화시키는 노동정책, 누진세와 사

2) “금융자유화로 인하여 풍부해진 금융자원은, 종종 빈곤층보다 이미 높은 소득·자산을 가지고 있는 부유층에게 '더 많은' 양이 귀착되기 때문이다. 또한 선진국의 경우, 해외 자본은 종종 기술 및 자본집약적인 첨단부문에 투자되기 때문에 고숙련 전문기술직의 임금을 상승시킴으로써 불평등을 강화한다. 개도국이나 후진국의 경우에는, 해외자본 이 주로 자원추출형 산업이나 제조업에 투자되기 때문에 농업노동자나 영세자영업자들 보다 높은 기술숙련도를 가진 노동자들에게 유리한 고용기회와 임금을 부여한다 (Jaumotte et al. 2013; Galbraith 2012). 이로써 선진국과 개도국 모두 금융자유화는 불평등을 증가시키는 경향이 있다.” 변영학, '금융자유화와 불평등의 국제정치경제: 세 계 44개국의 통계분석, 1980 2000', 『한국정치연구』 제22집 제2호, 227-250, p.241. 
회정책의 강화 대신 재정 안정성을 강조하는 재정정책 등이 그러한 국내정책으로 평 가된다(UNDP, 2013, pp. 83-95).

소득 이외 건강, 영양, 교육 등 인간개발 영역의 불평등에는 가구 간 소득 격차와, 정치적 요인, 정부의 사회복지 지출 정도, 특정 집단에 대한 스테레오타입, 편견 등 사회적 규범이 주요하게 영향을 미치는 것으로 알려져 있다(UNDP, 2013, pp. 144-151). 건강, 영양, 교육 영역에서 젠더 간, 지역 간 격차는 특히 정부 정책 및 사회적 규범과의 연관성이 큰 것으로 분석된다. 이는 가구의 소득 증가가 자동적으 로 가정 내 여성이나 여아의 삶의 질 증진으로 이어지는 것이 아니라는 점, 사회 내 존재하는 차별적 관행이 여성, 특정 지역에 거주하는 소수 인종·민족 등에게 자원이 나 기회가 불균등하게 주어지는 방식으로 작용한다는 점으로 설명될 수 있다. 다른 한편, 한 나라의 경제성장이나 소득수준은 그 사회 내 건강, 영양, 교육 등 영역에서 의 불평등 수준에 결정적 영향을 미치지 않는 것으로 나타났다. 즉, 불평등을 시정하 기 위한 정책적 노력이 별도로 필요한 것이다(UNDP, Ibid.).

\section{3. 불평등이 야기하는 사회적 효과}

불평등은 윤리적인 문제를 제기할뿐더러, 여러 측면에서 사회에 부정적인 효과를 야기한다. 불평등이 지속적인 성장을 어렵게 하고 빈곤 퇴치에 저해 요인으로 작용 한다는 다수의 연구들이 나왔다(World Bank, 2006; UNDP, 2013; IMF, 2014a, b). 세계은행의 세계개발보고서(2006)는 '불평등의 덫(inequality traps)'이라는 개념을 통해 경제·정치·사회·문화적 장치와 제도를 통해 사회집단들 사이에서 권력, 부, 지위 의 격차가 지속될 경우, 중·저소득층에 속하는 개인들이 그 사회 내에서 충분히 능력 과 자질을 발휘하지 못하는 환경을 구조화하기 때문에 그 격차가 크지 않은 상황에 비해 사회의 효율성이 낮다는 분석을 제시했고, 구조화된 불평등의 심각성에 대한 국제사회 차원의 논의를 불러일으켰다. IMF에서는 평등한 사회일수록 성장을 지속시 킬 수 있는 능력이 향상되는 결과를 보인다며, 단기적인 성장속도에만 초점을 맞추 어 불평등을 정당화하는 효과를 낳는 기존 논의3)의 한계를 지적하는 연구보고서가

3) 초기 개발경제학에서는 경제발전의 초기 단계에 있는 사회에서 불평등의 증가가 단계 적 특성으로 불가피하다는 이론이 주류를 이루어왔다. 
나왔다(Berg and Ostry 2011). 아시아개발은행의 2012년 공식리포트(ADB, 2012)는 1990년대 이후 아시아에서 불평등이 증가하지 않고 안정된 상태를 유지했다면, 지난 20 년 동안 추가로 2 억 4 천만 명의 사람들이 빈곤을 벗어날 수 있었을 것이라는 분석 을 제시하였다.

2014년 1월 개최된 세계경제포럼은 '글로벌 리스크 2014' 보고서를 통해 '소득 불 평등 문제가 향후 10 년간 세계 경제에 가장 큰 위험요인이 될 것'이라고 경고했으 며,(World Economic Forum, 2014) 유엔 경제사회사무국의 2013년 세계 사회 상황 보고서는 증가하는 불평등의 세계적 경향과 불평등이 미치는 부정적 효과에 대해 다 음과 같이 분석하였다.

불평등이 야기하는 다수의 부정적 결과는 단지 하위계층뿐 아니라 기존 분배구조 의 수혜자인 듯한 사람에게도 영향을 미친다. 최근 금융경제위기의 시작과 이어진 영향은 불평등이 사회경제적 발전에 어떤 해를 입히는지를 잘 드러내준다. 불평등은 경제성장을 제약하는 덜 안정적이면서 비효율적인 경제시스템으로 이어지고, 빈곤퇴 치를 심각하게 저해한다. 경제성장이 사회개발에 긍정적으로 기여하는 효과와 사회 계층 간 이동성을 감소시킨다(UN Department of Economic and Social Affairs, 2013, p.73).

부의 불평등은 교육, 건강, 영양상의 불평등을 양산하는 데 주요한 영향을 미친다. $\operatorname{UNDP}(2013$, p.145)의 연구에 따르면, 한 나라의 평균소득이나 성장의 정도는 그 사 회의 평균적인 교육, 건강, 영양수준과는 관련이 있지만, 교육, 건강, 영양상의 불평 등에는 결정적인 영향을 미치지 않는다. 즉, 국민소득 수준의 향상이 불평등의 완화 로 자동적으로 이어지지 않는다는 것이다. 다른 한편, 그 사회의 소득불평등은 교육, 건강, 영양상의 격차를 설명하는 데 주요한 요인이며, 교육, 건강, 사회서비스에의 접근의 격차는 좋은 일자리와 더 나은 소득을 추구할 수 있는 기회를 불평등하게 조 건 짓는다.

심각한 불평등은 민주주의를 위협하고, 그로 인한 사회적 갈등의 위험성을 높인다 (UNDP, 2013, pp.52-53). 불평등은 공적 의사결정에 영향을 미칠 수 있는 힘, 즉 
권력관계의 불평등을 동반한다. 경제적, 정치적 불평등이 심화되면, 더 큰 권력을 가 진 이들의 이익 보존에 편향된 정치제도나 사회정책을 양산하게 된다. 더 부유하고 정치적 영향력이 큰 사람들의 이익을 중심으로 공적자금이나 서비스가 배분되는 제 도가 구축, 강화되는 것은 민주주의를 저해할뿐더러, 정치사회적 불평등이 재생산되 는, 탈출하기 어려운 '불평등의 덫'을 형성하게 된다는 점에서 심각한 문제이다. 즉, 불평등이 심화되면, 가구의 소득에 따라 그 가구의 자녀가 받는 교육의 질에 현저히 차이가 생긴다. 교육의 질은 이후 자녀들이 성인이 된 후의 소득에 차이를 가지고 온다. 저소득층이기 때문에, 그(녀)의 부모가 그랬듯이 공교육에 대한 정부 예산 결 정과정에 영향을 미칠 수 있는 힘이 부유층에 비해 적고, 이는 불평등의 악순환으로 이어진다(World Bank, 2006, p.2). 불평등의 심화는 사람들 사이에서 제도에 대한 신뢰 및 사회연대감의 저하, 그로 인한 불관용과 차별 및 사회적 갈등의 증가와 밀 접한 연관이 있다는 연구가 다수 존재한다(Stiglitz 2011; Stewart 2008).

\section{II. 불평등과 인권}

\section{1. 개발에 대한 인권적 접근4)}

경제가 성장하고 부가 늘어난다 해도, 불평등의 심화, 정치사회적 참여의 제약, 차 별적 구조의 고착화 등이 개선되지 않는 한, 그러한 발전은 장기적으로 지속될 수 없다는 인식이 높아지고 있는 가운데, 개발의 방향성을 바로잡는 데 필요한 윤리적 법적 규범의 틀로서 강조되는 것이 인권이다. 개발에 인권을 접목하고자 하는 시도 는 1990년대 중반 무렵부터 시작되었는데, 국가 단위의 경제성장을 중심으로 하는 지배적인 개발관 하에서 빈곤과 불평등이 경제성장의 불가피한 부산물로 치부되고 빈곤층은 국가나 공여기관의 재량에 따라 서비스를 제공받는 수동적 수혜자로 전락 하는 현실에 대한 문제의식에서 비롯되었다.

4) 본 논문에서는 개발에 대한 인권적 접근의 내용을 간략히 소개한다. 보다 자세한 내용 은, 졸고(2013) '자선을 넘어 지구적 정의의 추구-국제개발에 대한 인권적 접근의 배 경과 의의', 『국제개발협력연구』제5권 제2호:97-129와 저자가 연구책임자로 참여했 던 2014년도 인권상황 실태조사 연구용역 보고서 『공적개발원조 정책의 현황 및 인 권적 개선방안 연구』중 '제1장 인권에 기반을 둔 개발협력' 참조. 
1948년 유엔 총회에서 채택되어 현대 인권규범의 기초를 제공하고 있는 세계인권선 언은 고문 및 잔혹한 처우 금지, 신체적 자유, 정치적 참여, 적정절차의 보장 등 시 민·정치적 권리뿐 아니라, 인간다운 생활에 필수적인 재화, 서비스 및 수단에 대한 권 리, 즉 건강권, 식량권, 교육권, 노동권, 주거권, 사회보장에 대한 권리를 포함하고 있다. 세계인권선언에 담긴 권리의 내용을 기속력 있는 법적규범화한 것이 1966년에 채택된 시민·정치적 권리에 관한 국제규약, 경제·사회·문화적 권리에 관한 국제규약이 다. 2015년 1월 21일 현재 시민·정치적 권리에 관한 국제규약, 경제·사회·문화적 권리 에 관한 국제규약을 비준한 국가의 수는 각각 168 개국, 163 개국이다. 인권이 실현될 수 있는 공정한 국내 및 국제 경제 질서에 대한 열망 속에 1986년 채택된 발전권 선 언은 '모든 사람과 모든 인민이 경제, 사회, 문화 및 정치적 발전에 참여하고, 기여하 고, 향유할 수 있는 권리'로 발전권을 정의하고, 모든 국가들은 인권이 존중되고 보호 될 수 있는 환경을 만들어 나가기 위해 협력해야 할 의무가 있음을 천명하였다.

빈곤은 다양한 인권의 박탈을 야기하고, 역으로 인권의 박탈은 빈곤상태를 벗어나 기 어렵게 만든다. 빈곤한 상태에 있는 사람들은 의식주를 포함하는 적절한 생활수 준에 대한 권리, 건강권, 교육권 등을 제대로 누릴 수 없을 뿐 아니라, 착취적 상황 에 노출될 가능성이 높고, 공적 의사결정에 참여할 기회와 발언권도 상대적으로 제 약된다. 이러한 상황은 빈곤이나 불평등이 지속되고 다음 세대로 재생산되는 악순환 을 낳기 쉽다. 따라서 인권적 관점에서는 빈곤이 단순한 결핍의 상태가 아닌, 인간으 로서의 존엄을 유지할 수 없는, 인권이 박탈된 상태이다. 국가는 국제인권법 하에서 발생하는 의무로서, 법, 정책, 관행과 문화 등에서 빈곤의 주요 원인을 규명하고 문 제를 해결해 나가야 한다. 국제인권조약 하에서 국가는 모든 사람들이 적절한 생활 수준에 대한 권리, 건강권, 교육권, 사회보장에 대한 권리, 인간다운 조건 하에서 일 할 권리를 누릴 수 있도록 보장해야 한다. 이러한 권리를 누리는 데 필수적인 서비 스가 충분한 수량으로 공급되고(availability), 지리적으로 접근가능하고 (accessibility), 경제적이고(affordability), 젠더, 연령, 장애, 문화적 차이 등을 고 려하며(acceptability), 질과 안전성(quality)에서 문제가 없어야 한다. ${ }^{5)}$ 사법접근권,

5) 유엔 경제·사회·문화적 권리위원회는 경제·사회·문화적 권리에 관한 국제규약 상의 권 리의 실현에 필요한 재화나 서비스는 수량적 측면(availability), 지리적 경제적 접근성 (accessibility and affordability), 젠더, 연령, 문화적 차이 등에 대한 수용성 (acceptability), 질과 안전성(quality) 등의 요건을 충족해야 한다고 해석한다. 
공적생활에 참여할 권리, 개인적 안전, 표현의 자유, 집회 결사의 자유를 보장하기 위한 조치를 취하는 것도 국제인권법 하 국가의 의무이다. 국가는 사람들이 차별 없 이 인권을 누릴 수 있도록 하여야 하며, 형식상의 평등을 넘어 사회적 약자의 권리 증진을 위한 적극적 조치 등 실질적 평등을 추구해야 한다. 유엔(2012b)은 인권과 기본적 자유에 대한 존중과 실현이 개발의 궁극적인 목적이어야 하며, 개발 과정에 서도 차별금지 및 평등의 옹호, 참여 증진, 권리주체로서의 역량강화, 권력기관의 책 무성 강화 등 인권의 원칙이 기본 바탕을 이루어야 한다는 점을 거듭 강조해 왔다. 인권은 어느 상황에서든 존중, 보호되어야 할 내재적 가치를 갖고 있을 뿐 아니라, 보다 형평성 있고 지속가능한 개발을 도모하는 데 기여할 수 있기 때문이다.

\section{2. 차별금지와 평등: 국제인권규범의 기초}

21세기 국제사회가 직면한 점증하는 불평등의 현실은 다수의 시민들이 체계적으로 발전의 혜택에서 소외되고, 그 양상이 소득, 건강, 교육 등 생활의 여러 측면으로 드 러난다. 또한 이러한 불평등은 젠더, 인종, 민족, 장애, 거주지역 등에 따른 차별과 연관되어 더욱 증폭되어 나타난다. 심각한 불평등은 평등하게 권리를 누리지 못하는 개개인들의 존엄성에 대한 부정이며, 사회적인 차원에서는 시민들 간의 연대성을 약 화시키는 주요한 원인이 된다. 이러한 현실을 개선해 나가는 데 차별금지와 평등이 라는 인권의 원칙은 핵심적이다.

평등을 향한 열망은 인권의 기본적 토대가 되는 가치이자, 국제인권규범에 담긴 가장 핵심적인 약속이다. 유엔헌장(1945)의 전문은 '기본적 인권, 인간의 존엄 및 가 치, 남녀 및 대소 각국의 평등권에 대한 신념을 재확인’한다. 1948년 12월 10일 유엔 총회에서 채택된 세계인권선언은 제 1 조에서 '모든 인간은 태어날 때부터 자유로우며 그 존엄과 권리에 있어 동등하다. 인간은 천부적으로 이성과 양심을 부여받았으며 서로 형제애의 정신으로 행동하여야 한다'고 차별금지와 평등을 기본 가치로 천명하 였다. 세계인권선언에서 표방된 인권의 내용을 법적으로 성문화한 양대 인권규약, 시 민·정치적 권리에 관한 국제규약(1966), 경제·사회·문화적 권리에 관한 국제규약 (1966)은 각각 제 2 조 제 1 항과 제 2 조 제 2 항에서 모든 인권을 누림에 있어서 차별금지 와 평등의 원칙이 존중되어야 함을 규정하였다. 아울러, 많은 사람들이 인종, 성별/ 
젠더, 장애 등으로 차별과 불이익을 경험하고 있음을 인지하며, 인종, 성별, 장애로 인한 차별을 금지하고 실질적 평등을 옹호하기 위한 목적으로, 모든 형태의 인종차 별철폐에 관한 국제협약(1966), 여성에 대한 모든 형태의 차별철폐에 관한 국제협약 (1979), 장애인권리협약(2006)이 채택되었다.

인종차별철폐협약(1966), 여성차별철폐협약(1979)에서는 차별의 의도성이 인지되는 경우뿐 아니라 의도와 무관하게 차별적 효과가 나타나는 경우 역시 차별의 범위로 포함하며, 양대 인권규약의 이행을 감독하는 유엔 전문가위원회들(UN CESCR, 2009, p.3; UN CCPR, 1989, p.2)도 이 같은 해석을 따르고 있다. 이는 동일성 비 교에 근거해 동일한 상태로 인정될 경우 동일한 대우를 핵심으로 하는 형식상의 평 등을 넘어, 실질적 평등의 보장을 요구한다. 유엔 경제 · 사회 · 문화적 권리위원회 (2009, p.4)는 '형식상의 차별을 시정하는 것으로는 제 2 조 제 2 항에서 전제하고 있는 실질적 평등을 보장할 수 없다. [...] 실제에서 차별을 철폐하는 것은 유사한 상황에 있는 개인에 대한 형식상의 대우를 단순 비교하는 것 대신, 역사적으로 혹은 지속적 으로 편견을 경험한 개인들의 집단에 충분한 관심을 가져야 함을 요구한다.'고 강조 하며, 이와 관련한 당사국의 의무를 다음과 같이 밝혔다.

당사국은 실질적 혹은 사실상의 차별을 야기하거나 영구화하는 조건과 태도를 예방, 완화, 폐지하기 위해 필요한 조치를 즉각적으로 취해야 한다. 예컨대, 모든 개인들에게 적절한 주거, 식수 및 위생시설에 대한 평등한 접근을 보장하는 것은 여성, 여아, 비공 식주거지와 농촌지역에 사는 사람들에 대한 차별을 극복하는 데 도움이 될 것이다.

실질적 차별을 철폐하기 위해, 당사국은 차별을 지속시키는 조건을 약화시키거나 없애기 위해 어떤 경우에는 특별한 조치를 취해야 할 의무를 갖는다. 사실상의 차별 을 시정하기 위한 합리적이고 객관적이고 비례성에 부합하며, 실질적 평등이 지속가 능하게 실현될 때는 중단된다는 조건 하에서, 그러한 특별 조치는 정당하다. 하지만 예외적으로 그러한 적극적 조치가 영구적일 필요가 있다. 언어 소수자를 위한 통역 서비스, 감각장애를 가진 사람들이 보건시설을 이용할 수 있도록 하기 위한 합리적 인 편의시설 등이 그러한 예이다(UN Committee on Economic, Social and Cultural Rights, 2009, p.4). 
앞서, 유엔 시민·정치적 권리위원회도 사실상의 차별을 야기하고 그러한 차별을 지 속시키는 조건에 주목하며, 그러한 조건을 시정하기 위한 구체적 조치의 필요성을 강조하였다(UN CCPR, 1989, p.2). 사실상의 차별을 철폐하고 실질적 평등을 보장하 기 위한 적극적 조치의 필요성은 인종차별철폐협약(1966), 여성차별철폐협약(1979), 장애인권리협약(2006)에서도 재확인된다. 인종차별철폐협약 제 2 조 제 2 항은 인종에 관계없이 완전하고 평등한 인권과 기본적 자유의 향유를 보장하기 위해, '상황이 적 절한 경우 사회적 경제적 문화적 그리고 기타 분야에 있어서 특정 인종집단 또는 개 인의 적절한 발전과 보호를 보증하는 특수하고 구체적인 조치'를 취하여야 한다고 규 정한다. 여성차별철폐협약 제 4 조 제 1 항은 '남성과 여성 사이의 사실상의 평등을 촉진 할 목적으로 당사국이 채택한 잠정적 특별조치’를 허용한다. 장애인권리협약 제 5 조 제 3 항은 '평등을 증진하고 차별을 철폐하기 위하여, 합리적인 편의 제공을 보장하기 위한 모든 적절한 절차'를 취하여야 한다고 명시한다.

\section{3. '실질적 평등' 의 내용}

실질적 평등을 보장하기 위한 정책적 조치의 방향성을 논의하기 위해서는, 인권 원칙으로서의 평등의 대상과 목적이 무엇인지 좀 더 분명히 할 필요가 있다. 가장 협소한, 하지만 가장 널리 적용되는 평등의 개념은 동일한 상황에 있다고 간주되는 사람들은 동일하게 대우해야 한다는 것이다. 동일노동, 동일임금의 원칙이 그 대표적 인 예이다. 동일대우 원칙의 주요한 한계는 이미 존재하는 사회경제적 불이익 혹은 차이로 인해 이질적 조건에 있을 수밖에 없는 사람들의 현실을 간과하고, 동일 대우 로서 그러한 불균등한 조건과 그로 인한 불평등을 더 견고하게 만들 수 있다는 점이 다(Fredman, 2014, p.9).

\section{1) 분배정의를 중심으로 한 평등이론}

형식적 평등을 넘어 실질적 평등의 내용적 토대를 정립하는 데 영향을 미친 여러 사상가들이 있다. 특히 사회경제적 불평등과 관련해, 분배 정의에 대한 이론을 제시 한 대표적 사상가들로 존 롤스(1971), 아마르티아 센(1992), 로날드 드워킨(1981), 존 로메(1998)를 꼽을 수 있다. 롤스는 사회경제적 불평등은 사회의 최소 수혜자들의 이 
익 개선에 가장 효과적으로 기여할 수 있도록 조정되어야 한다는 차등의 원리와 직 책, 직위 및 권한, 경제적 부와 같은 사회경제적 재화는 모두에게 개방되고 공정한 기회 균등의 원리에 따라 배분되어야 한다는 원칙을 제시하였다. ${ }^{6)}$ 즉, 롤스의 정의 론은 사회경제적 약자의 불이익을 개선하기 위한 제도와 정책의 필요성을 이론적으 로 뒷받침한다.

센(1992)은 사람들은 다른 자질과 특성을 갖고 있기 때문에, 같은 재화를 가지고서 도 성취할 수 있는 것이 다르다는 점을 인지하며 균등대우(equal treatment)의 한계 를 넘어서고자 하였다. 또한 재화는 그 자체로 가치가 있는 것이 아니라, 사람들이 추구하는 삶을 실현하는 수단이라는 점에서 재화의 배분을 중심으로 한 평등 이론의 한계를 지적하였다. 센(1992)은 기초재와 같은 재화 그 자체보다는, 질병으로부터의 해방, 적절한 영양 섭취, 자존감의 확보, 사회일원으로서의 생활 영위 등과 같은 다 양한 기능(functioning)을 성취할 수 있는 기본적 역량(basic capabilities)의 배분이 평등의 대상이 되어야 한다고 제안했다. 이때, 역량은 실제로 측정하기 어렵기 때문 에, 소득집단, 젠더, 인종, 민족, 장애 및 이들 중 중첩적 요인 등에 따른 기본적 역 량의 불평등 정도는 결과에 비추어 유추하게 된다.

드워킨(1981)은 개인의 선택에 따른 차이는 긍정하지만, 타고난 재능, 장애, 경제 적 배경 등 개인이 통제할 수 없는 변수의 작용에 의해 발생한 불평등은 사회가 보 상해 주어야 한다는 정의론을 제시했다. 드워킨에 영향을 받은 로머(1998)는 개인의 선택과 노력에 의해 발생한 소득 격차는 인정하되, 자신이 통제할 수 없는 환경적 요인으로 인한 불평등을 해소할 공공정책을 요구하는 '기회균등 정책'을 제안하였다. 위 네 사상가들의 이론은 서로 간에 차이가 존재하나, 개개인들이 통제하기 어려운 여건들이 개개인들이 성취할 수 있는 결과나 그 결과를 추구하기 위한 기회나 역량 에 영향을 미친다는 점을 인지하고, 그로 인해 발생하는 불이익의 시정을 강조한다 는 점에서 공통적이다.

6) 롤스의 정의론은 기회균등의 원리, 차등의 원리에 선행하여 모든 사람은 다른 사람들 의 자유와 상충되지 않는 한도 내에서 가장 광범위한 자유를 누릴 동등할 권리를 갖는 다는 것을 제1원칙으로 한다. 


\section{2) 인권으로서의 실질적 평등이 추구하는 방향}

산드라 프레드만(2014)은 평등에 관한 기존의 이론과 법리를 토대로 인권의 원칙 이자 핵심적인 권리로서의 평등의 의미를 재탐색하였다. 프레드만은 결과의 평등, 기 회의 평등, 평등이 추구해야 할 가치로서의 '존엄(dignity)', 이처럼 평등의 의미를 구성할 수 있는 개념들을 재검토하면서, 평등에 대한 다면적 이해를 제안한다. 일관 성 있는 대우, 절차적 공정성에 기초하는 '형식적 평등'이 이미 존재하는 불평등한 조건의 문제를 다루지 않는다면, '결과의 평등'은 대우가 아닌 결과의 공정성에 주목 함으로써 이러한 한계를 넘어선다. 앞서 보았듯이, 인권법에서는 법, 정책, 제도 등 이 모든 사람에게 동일하게 적용된다고 하더라도, 젠더, 인종, 장애 등 국제인권법이 차별을 금지하는 사유와 연관하여 어떤 특정 사람들이 권리를 향유하는 것을 가로막 는 효과를 낳는다면, 이를 간접적 차별로 규정한다. 차별적 효과를 발생시키는 법, 정책, 제도는 개선되어야 하고, 나아가 구조화된 불이익과 차별을 경험하는 집단을 우대하는 적극적 조치가 요구되기도 한다. 결과의 평등론이 갖는 한계는 학교, 의회 내 남녀 혹은 인종 간 불균등한 비율을 시정하기 위해 결과를 재조정하는 조치(특정 비율 할당제 등)가 차별적 결과에 이르는 과정, 즉 차별과 배제를 지속시키는 구조에 대한 인식과 그러한 구조의 개혁을 반드시 동반하는 것은 아니라는 점이다 (Fredman, 2014, p.13).

균등대우가 역사적, 구조적 차별이 온존하는 상황에서 기존의 불이익을 고착화시 킬 수 있다는 점을 인지하고 극복하려 한다는 점에서 기회의 평등론과 결과의 평등 론은 공통적이다. 하지만 기회의 평등론은 결과보다는 출발선을 평등화하는 데 주안 점을 둔다. 동시에 개인의 선택을 중요시한다. 따라서 구조화된 차별의 문제가 극복 되어 기회의 평등이 보장된다면, 개개인들의 선택에 따른 결과의 다름은 문제가 되 지 않는다. 기회의 평등론 내에는 기회를 평등하게 한다는 것의 의미를 둘러싼 관점 의 차이가 존재한다. 절차적인 차원에서 여성이나 여타 사회적 약자의 진입을 가로 막는 걸림돌을 제거하는 것을 중심으로 하는 기회의 평등은 그 자체로 의미가 있지 만, 사회적 약자들이 구조화된 차별의 결과 혹은 집단이 갖는 특성으로 인해 실질적 으로 그러한 기회를 활용할 수 있는 조건이 되지 못하는 상황을 묵인할 수 있다는 점에서 한계가 있다. 즉, 절차적 공정성이 보장된다 하더라도, 소득과 자산, 개인이 
갖는 특성 등에서 이미 존재하는 불이익으로 인해 각자에게 열린 기회의 폭이 실질 적으로 다를 수 있다는 점을 간과한다.

이러한 점에서, 실질적 의미의 기회의 평등은 예를 들면, 교육, 훈련, 일-가정 양 립 정책, 편의시설 제공 등 모든 사람들이 실질적으로 그 기회를 활용할 수 있도록 증진하는 적극적 조치를 요구한다. 직위, 권한, 기타 사회적으로 가치 있는 재화에 접근할 수 있는지 여부를 결정하는 기준이 이미 존재하는 불이익의 양상을 더욱 공 고히 하는 것이라 여겨진다면, 그러한 기준의 변경을 요구하기도 한다. 이 같은 광의 의 기회의 평등은 아마르티아 센이 제안하고 유엔인간개발보고서에서 널리 사용하는 개념인 역량(capabilities)의 평등으로도 달리 말할 수 있다.

제 I장

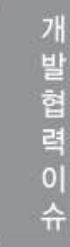

제II장

제피장

제IV장

평등권이 추구하는 내용적 가치를 찾고자 하는 시도들이 있고, 여러 나라 법원의 평등권 적용 사례들은 평등권을 통해 근본적으로 옹호하고자 하는 가치가 인간 존엄 성이라고 보는 시각을 내재하고 있다(Fredman, 2014, p.17). 이러한 관점에서 보면, 어떤 사람들을 부당하게 다르게 대우하여 그들이 마치 이등시민인 것처럼 느끼게 하 는 것, 그로 인해 인간으로서 기본적인 존엄이 훼손되지 않도록 보장하는 것에 평등 의 핵심이 있다. 모든 사람은 인간으로서의 존엄을 지니고 있고, 그것이 훼손되어서 는 안 된다는 원칙은 법률을 넘어서 강한 보편 윤리적 힘을 갖는다. 또한 인간존엄 을 평등의 핵심에 위치 짓는 관점은 인권으로서의 평등권의 기본선을 재확인함으로 써 평등의 옹호가 하향 평등화로 귀결될 수 있다는 문제제기에 대해 일정한 응답을 제공할 수 있다(Fredman, 2014, p.17). 단, 인간 존엄성이라는 개념 역시 해석을 필 요로 하고 다양한 의미를 내포할 수 있다는 점을 인식해야 한다.

결과의 평등, 기회의 평등, 인간 존엄을 기초로 하는 평등론은 균등대우의 원칙이 라는 협소한 평등 개념이 지니는 한계를 극복하는데 각기 다른 내용적 기여를 한다. 이러한 논의를 토대로, 프레드만(2014, pp. 21-33)은 인권에서 실질적 평등이 추구 해야 하는 것을 첫째, 사회적 약자들이 경험하는 불이익의 개선, 둘째, 편견, 사회적 낙인, 스테레오타이핑, 모욕과 폭력에 대한 대응, 셋째, 사람들이 지닌 다양한 특성 들이 충분히 고려될 수 있도록 하는 사회구조의 개혁, 넷째, 사회적 배제의 극복과 사회적 약자의 사회적·정치적 참여 증진에 두자고 제안한다. 
첫째, 사회적 약자들이 경험하는 불이익을 개선한다는 방향성은 중립성을 추구하 는 형식적 평등을 넘어, 불이익을 시정하고 실질적 평등을 위한 적극적 조치의 필요 성을 제기한다. 이러한 적극적 조치는 수적인 결과의 평등을 전제하기보다는, 사회적 으로 형성된 불이익이 시정되었는지에 초점을 둔다. 불이익의 성격은 일자리, 직위, 교육기관, 기타 사회경제적 재화에 대한 접근 등 재화의 불균등한 분배로 드러나는 부분이 많지만, 실질적인 기회의 선택과 의사결정을 어렵게 하는 불균등한 권력의 분배 역시 중요한 측면이다. 따라서 불이익을 개선한다는 것은 사람들에게 실질적인 선택을 할 수 없도록 만드는 경제적 기회, 사회정치적 제약, 기본적인 건강, 교육, 의식주를 영위할 수 있게 하는 조건의 불균등함을 시정해야 함을 의미한다.

둘째, 사회적 불이익은 젠더, 민족, 인종, 장애, 성적지향 등이 연관되어 특정 집 단에게 집중되는 경우가 많다. 그러한 불이익은 그 집단이 갖는 정체성에서 비롯되 는 것이 아니라, 그 집단에 대한 사회적 태도에서 기인된다. 그러한 점에서 젠더, 민 족, 인종, 장애, 성적 지향 등에 근거한 사회적 낙인, 스테레오타이핑, 모욕과 폭력 에 대응하는 것은 실질적 평등의 또 하나의 중요한 측면이다. 사회경제적 불이익을 시정하기 위한 노력이 사회적 낙인, 스테레오타이핑을 강화하지 않도록 주의를 기울 여야 할 필요성도 제기된다.

셋째, 각 개인들은 각기 다른 특성을 가지고 있다. 실질적 평등은 차이에 근거 해 가해지는 불이익의 요소를 제거하는 한편, 차이가 인정되고 수용될 수 있도록 사회제도의 개선을 추구해야 한다. 자녀양육을 병행할 수 있도록 노동시간을 조정 한다거나, 장애인과 노약자를 위해 편의시설을 제공하는 것, 종교적 민족적 소수 자의 문화를 존중하는 것 등이 차이를 인정하고 수용할 수 있는 사회제도적 변화 의 예이다.

넷째, 불평등은 정치적 참여의 제약으로 드러나기도 하고, 역으로 정치적 참여의 결여는 기존의 불평등을 개선하도록 정치구조를 변화시킬 기회를 차단함으로써, 불 평등의 공고화를 야기한다. 실질적 평등은 사회적 약자들이 스스로 자신의 관점과 요구를 밝히고, 그러한 내용이 의사결정에 영향을 미칠 수 있는 다양한 정치적 참여 의 통로를 마련할 것을 요구한다. 실질적 평등이 추구하는 평등한 참여의 기회의 증 
진은 정치적 참여에만 국한되지 않고, 다양한 사회생활에 개개인들이 참여할 수 있 는 다양한 정책적 노력을 수반해야 한다.

프레드만이 제시한 인권으로서의 실질적 평등의 내용은 분배, 사회적 인정(認定), 차이를 수용할 수 있도록 하는 구조적 변화, 참여에 중요성을 두고 각기 독립적으로 발전되어 온 평등론7)을 토대로 하면서, 각각이 제기하는 평등의 중요한 측면들을 종 합적으로 사고할 수 있도록 돕는다는 데 그 강점이 있다. 아울러 실질적 평등의 네 가지 측면은 $\triangle$ 건강권, 식량권, 교육권, 주거권, 사회보장에 대한 권리 등 사회경제 적 권리, $\triangle$ 차별과 모욕을 당하지 않을 권리, 안전을 위협당하지 않을 권리, 공정한 절차에 대한 권리, 정치적 참여의 권리 등 시민 정치적 권리, $\triangle$ 공동체생활에 참여하 고 문화를 향유할 권리와 같은 문화적 권리 등 보편적 인권의 다양한 내용을 평등하 게 누릴 수 있도록 보장하는 것으로 표현될 수도 있다. 다른 한편, 기회의 불평등과 결과의 불평등의 상호연관성에 대한 인식을 통해, 그러한 불평등을 야기하는 사회적 제도나 관행이 무엇인지를 밝히고 개선하도록 요구한다는 점에서도 의의가 있다. 이 러한 인식은 기회의 불평등은 결과의 불평등에 대한 분석을 동반할 때 의미 있는 개 선책이 도출될 수 있다고 보는 유엔의 개발 주무기관인 유엔디피의 관점과도 맞닿아 있다(UNDP, 2013, pp. 30-31).

\section{Post-2015 지속가능 발전의 기초로서의 인권과 평등}

\section{1. 불평등 완화, 평등 증진을 위한 정책의 방향성}

불평등을 완화하고 평등을 증진하기 위해 국제사회와 각국의 정부는 어떤 정책적 방향성 하에 빈곤 감소와 사회 발전 전략을 수행해야 할 것인가에 대해 세계은행 (2006), 유엔사회개발연구소(2010), 유엔디피(2013) 등 개발 관련 기구들이 제시하는 정책적 방향에는 일정한 시각의 차이에도 불구하고 공통적 흐름이 존재한다.

7) 프레드만은 분배정의에 대한 다양한 정치이론들 외에도, 낸시 프레이저, 악셀 호네트 등이 제기한 인정, 참여를 포괄하는 정의론에서도 영감을 받았다고 밝히고 있다. Nancy Fraser \& Alex Honneth(2004) 『Redistribution or Recognition』, Verso. 
기본적 관점으로는, 동등대우, 절차적 공정성에 국한한 평등의 개념을 넘어, 실질 적 기회의 평등 증진을 추구한다. 결과의 평등을 어느 정도 적극적으로 추구할 것인 가에 대해서는 차이가 있다. 세계은행(2006, p.2)은 모든 개인은 인종, 젠더, 사회경 제적 배경, 출신국과 같이 정해진 조건과 관계없이, 재능과 노력을 통해 자신이 원하 는 삶을 추구할 수 있어야 하며, 건강, 교육, 소비 수준 등 결과에 있어서 빈곤한 상 태에 처하지 않을 수 있어야 한다는 의미로 형평(equity)의 증진을 추구한다. 이는 실질적 기회의 평등을 중심으로 하되, 결과의 측면에서는 빈곤 상태의 방지에 초점 을 둔 접근이다. 이러한 접근 하에서는 교육, 보건 부문에 대한 투자 등 경쟁의 출발 선을 평등화하기 위한 정책적 개입 및 재분배가 장려되나, 사회보장 부문에서는 사 람들을 빈곤선 아래로 떨어지지 않도록 하는 사회안전망 중심의 소극적 접근으로 귀 결될 수 있다. 유엔사회개발연구소(2010, p.12)나 유엔디피(2013, pp.30-33)는 결과 의 불평등이 심각한 경우 기회의 평등을 증진하는 데도 한계가 있다는 점과 결과의 불평등 상황이 지속되어 고착화되면 사회적 약자집단에 대한 차별과 편견이 견고해 지고, 사회적 연대를 어렵게 한다는 점을 지적한다. 이러한 관점 하에서, 교육, 보건 부문의 강화를 통해 기회의 평등을 증진하고, 빈곤층만 구분하여 최소한의 생존을 보장하는 데 치중하는 사회안전망 중심의 소극적 접근을 넘어 보편적인 사회보장의 확대를 통해 결과의 평등을 증진하는 접근을 권고한다.

위 연구들(World Bank, 2006; UNRISD, 2010; UNDP, 2013)은 각각 불평등을 해소하기 위한 정책의 포괄적인 방안을 제시하고 있는데 주요 내용은 아래 세 가지 로 요약될 수 있으며, 이러한 방향성은 인권적 접근과도 맞닿아 있다. 첫째, 공공지 출을 통해 교육, 보건, 식수 및 위생 부문 등 사회 서비스를 확충하고, 아동·노인을 비롯해, 질병·장애·실업·임신 및 출산 등으로 소득이 없는 개인 및 가구를 위한 소득 보장 등의 사회보장정책을 강화할 것. 적절한 수준의 법인세, 소득 및 자산에 대한 누진세, 공적개발원조를 통해 재원을 확보할 것. 이는 교육권, 건강권, 주거권, 적절 한 생활수준에 대한 권리, 사회보장에 대한 권리를 실현하는 데 필요한 조치들이면 서, 소득, 교육, 건강 등에서 나타나는 인간개발 상의 불평등을 해소하는 데 기여한 다. 나라의 상황에 따라 빈곤층에 국한된 별도의 사회보장 프로그램을 시행하는 것 도 가능하나, 빈곤층과 그렇지 않은 사람들이 사용하는 사회서비스 간 격차로 인한 또 다른 불평등과 사회적 낙인을 낳을 수 있다는 점에서 궁극적으로는 보편적 사회 
보장을 지향해 나가야 한다는 견해도 적극 고려되어야 한다(UNRISD, 2010, pp. 135-160; Melamed and Samman, 2013, p.20).

둘째, 괜찮은 일자리(decent job)를 많이 창출하는 포용적 경제성장을 추구할 것. 이는 고용창출 없는 경제성장과 더불어, 숙련기술 우대와 저임금, 불안정한 고용형태 의 증가, 노사 간 힘의 불균형 증가로 인해 소득불평등이 가속화되고 있고, 서민과 중산층을 경제발전의 혜택으로부터 소외시키는 경제패턴을 전환하지 않은 채 재분배 정책만으로는 불평등의 간극을 줄이기에 부족하기 때문이다(UNDP, 2013, pp.4-5). 여기서 괜찮은 일자리는 임금, 고용형태, 노동자들의 권리 보호에 있어 적절한 일자 리를 의미한다. 괜찮은 일자리 창출을 중심으로 하는 포용적 경제는 노동권, 적절한 노동조건에 대한 권리, 적절한 생활수준에 대한 권리, 발전의 과정에 참여하고 그 혜 택을 고루 누릴 수 있어야 한다는 발전권의 권리 실현을 위해 경제 부문에서 요구되 는 개혁의 방향성이기도 하다.

셋째, 젠더, 인종·민족, 장애, 거주지역 등에 근거한 차별을 금지하고, 차별적인 사 회적 규범, 관습, 태도를 타파하고, 사회적 약자층의 시민·정치적 권리의 강화를 통 해 사회정치적 지위를 증진하고, 이들의 의사가 사회제도와 정책을 결정하는 정치적 과정에 좀더 폭넓게 대표될 수 있도록 하는 것이다. 이는 소득, 건강, 교육상에서의 불평등이 젠더, 인종·민족, 장애, 거주지역 등에 근거한 차별로 인해 더욱 강화되고, 세대에 걸쳐 재생산되는 경향이 나타나고 있기 때문이다(Kabeer, 2010, p.6; Melamed and Samman, 2013, pp.9-10; UNDP, 2013, p.2). 세계은행(2006, p.2) 은 빈곤이 대물림되고 불평등이 유지, 강화되는 이러한 현상을 '불평등의 덫'이라고 묘사하면서, 가장 효과적인 빈곤감소 정책은 한 사회 내의 지배적인 집단에 집중된 정치적 영향력을 재분배하는 것이라고 강조하였다.

고도로 불평등하게 집중된 부는 편중된 정치권력과 결부하여 제도적으로 개인들의 권리와 재산권이 폭넓게 집행되는 것을 가로막고(특정 계층에게) 유리하게 서비스가 제공되고 시장이 기능하도록 만든다. 의사표명을 통해 영향력을 미칠 수 있는 힘과 공적자원이 지배적인 집단에서 더 적은 기회를 가진 이들에게 재분배되지 않는다면, 이러한 현실은 바뀌기 어렵다(세계은행, 2006, pp.9-10). 
차별적인 제도와 사회규범을 개선하고, 빈곤층 및 사회적으로 소외된 집단들의 표현 의 자유, 집회결사의 자유, 참여의 권리를 보장하는 것은 인권의 요구일 뿐 아니라 빈 곤과 불평등을 고착화하는 근본적인 요인을 찾고 해결해 나가는 데 있어 필수적이다.

\section{Post-2015 지속가능 발전목표(SDG)를 통한 평등의 증진}

사회 불평등 문제는 MDG 체제가 누락한 중요한 범 분야 이슈이다. 전 세계 189 개 국 지도자들은 2000년 새천년선언(Millennium Declaration)을 채택하면서 빈곤퇴치 를 인류의 최우선 과제 중 하나로 합의하였고, 이러한 약속의 실행을 위해 8개의 목 표로 구성된 MDGs가 채택되었다. 새천년선언(2000)은 '누구든 어떤 나라든 발전의 혜택을 누릴 기회가 부인되어서는 안 된다'며 인간의 존엄성, 평등, 형평의 가치를 지켜나갈 각국과 국제사회의 책임을 분명히 하였다. 하지만 MDGs 각 개발목표의 달 성정도를 국제 및 국내 평균을 중심으로 측정하고 평가하도록 함으로써, 해당 국가 내 지역 간 혹은 그룹 간 격차는 관심의 초점에서 벗어났다. 상대적으로 여건이 나 은 그룹에게 자원을 집중하는 것이 평균 수준의 상승을 통한 일부 세부목표의 달성 을 더 용이하게 할 수 있기 때문에, $\mathrm{MDG}$ 체제 하에서 최빈층 혹은 여타의 사회적 약자들에서 그보다 나은 계층으로 자원이 이전했을 가능성도 완전히 배제할 수 없다. $\mathrm{MDGs}$ 는 소득 이외 교육, 건강, 영양 등 빈곤의 다양한 측면을 포괄했다는 점에서 이전의 협소한 개발담론에서 진일보한 측면을 보였으나, 불평등 문제를 외면했다는 점이 중요한 한계로 평가되었다(Kabeer, 2010, p.6; Melamed and Samman, 2013, p.1; UN, 2012a, p.3).

MDG 체제가 종료되는 2015년부터 2030년까지 국제개발의 새로운 의제가 될 Post-2015 개발의제의 준비 과정에서 주목할 것은 불평등의 해소가 핵심 의제 중 하나로 부상되었다는 점이다. 유엔, $\mathrm{OECD}$, 다보스포럼 등 각종 국제 논의의 장에서 사회불평등이 지속가능한 발전과 빈곤 감소를 심각하게 저해하고 있어, 각국 정부와 국제사회가 불평등의 완화를 위해 특별한 노력을 기울여야 한다는 데 대해 폭넓은 합의가 이루어지고 있다는 점에서 자연스러운 결과이다. Post-2015 개발의제 준비를 위한 유엔 시스템 타스크팀은 불평등 해소라는 과제를 효과적으로 Post-2015 개발 의제에 반영하기 위해 2012년 이 주제와 관련한 보고서를 제출하였고, 고위급 패널 
은 2013년 5월 근본적 변화를 위한 5개의 주요 비전 중 첫 번째로 '누구도 소외되지 않는 발전(Leave no one behind)'을 설정하였다. 같은 해 8월 반기문 유엔 사무총장 의 보고서, '모든 사람들에게 존엄한 삶을(A Life of Dignity for All)'은 이러한 제 안들을 반영해, 보편적 인권에 기반을 둔 지속가능한 발전목표(Sustainable Development Goals: SDG)를 발전시킬 것을 권고했다. 2014년 7월 지속가능발전목 표(SDG) 공개작업반은 17 개의 목표8)와 169 개의 관련 세부목표(안)을 제안하였는데, 17 개 목표에는 평등 증진과 관련된 목표(목표 10: 불평등 완화, 목표 5: 성평등 증 진)가 두 개 포함되어 있다. 아래는 그 중 지속가능발전 목표 〈10: 국내 및 국가 간 불평등 완화> 하의 7 가지 세부목표이다.

\section{지속가능발전 목표 10(안): 국내 및 국가 간 불평등 완화}

10.1 2030년 내로 소득분배에서 하위 $40 \%$ 에 해당하는 인구의 소득을 국가 전 체 평균 수준 이상까지 점진적으로 확대하고 유지하도록 한다.

10.2 2030년까지 연령, 성별, 장애, 인종, 민족, 출신지, 종교, 경제 및 기타 지 위와 관계없이 모든 사람들이 사회, 경제, 정치적으로 참여할 수 있도록 역량을 강화(empower)하고 그러한 참여를 증진한다.

10.3 차별적 법률, 정책, 관행을 폐지하고, 이와 관련한 적절한 법률, 정책, 행 동을 증진함으로써 기회의 평등을 보장하고 결과의 불평등을 완화한다.

10.4 재정, 임금, 사회보장 등에 대한 정책을 채택하고 점진적으로 더 나은 수 준의 평등을 달성한다.

10.5 국제금융시장과 기구의 규제와 모니터링을 개선하고, 관련 규제의 이행을 강화한다.

10.6 국제경제·금융기구 내 의사결정에서 개발도상국의 대표성과 발언권을 확대 하여 효과성, 신뢰성, 책무성, 정당성이 보장되는 제도를 구성한다.

10.7 이주정책을 계획하고 세심히 관리하여, 정연하고, 안전하고 정규적이고 책

8) 공개 작업반이 제안한 17 개 목표는 다음과 같다. (1)빈곤퇴치 (2)기아 퇴치, 식량안보, 지속가능한 농업 증진 (3)보건 증진 (4)형평성 있는 양질의 교육 보장 (5)양성평등 (6)물 과 위생시설의 보장 (7)경제적이고 지속가능한 에너지 공급 (8)포용적이고 지속가능한 경제성장, 모두를 위한 좋은 일자리 증진 (9)인프라 건설 (10)불평등 완화 (11)지속가능도 시 (12)지속가능 소비생산 (13)기후변화 대응 (14)대양, 바다, 해양자원의 보존과 지속가능 성을 고려한 이용 (15)생물다양성과 생태계 보호 (16)사법권 접근 보장과 효과적이고 책무 성을 갖춘 제도 구축 (17)이행수단의 강화와 글로벌 파트너십의 활성화. 
임있게 인구의 이주와 이동이 이루어지도록 촉진한다.

10.a WTO 협정에 따라, 개발도상국, 특히 최빈국에 대한 우대 원칙을 실행한다. 10.b ODA 및 외국인직접투자(FDI)를 포함한 기타 재정적 흐름이 가장 필요한 국가, 즉 저개발국, 아프리카 국가, 군소도서 개발도상국, 내륙 개발도상국 등에 이어질 수 있도록 장려하며, 해당국의 계획과 프로그램에 부합하도록 한다. 10.c 2030년까지 이주자 송금의 거래비용을 $3 \%$ 미만으로 줄이며, $5 \%$ 이상의 비용이 청구되는 송금통로를 없애도록 한다.

'누구도 소외되지 않는 발전'으로 대표되는 불평등 완화의 비전은 (1)빈곤퇴치 (2)기 아 퇴치, 식량안보, 지속가능한 농업 증진 (3)보건 증진 (4)형평성 있는 양질의 교육 보장 (5)양성평등 (6)물과 위생시설의 보장 (7)경제적이고 지속가능한 에너지 공급 (8) 양질의 일자리 증진 등 다른 목표에도 반영이 되어 있다. 소득빈곤, 건강, 교육, 영 양, 정치사회적 참여, 식수 및 위생 등 개별적 인간개발 지표 상 진보를 평가할 때, 젠더, 소득, 지역, 인종·민족 등 주요 차별요인에 따라 분류된 데이터를 수집해, 그 룹 간 격차를 함께 측정하고 격차를 좁히도록 하는 것이 다른 목표를 성취하는 과정 에서도 불평등을 완화하기 위한 주요한 방식이다. 또 하나는 (1)빈곤퇴치, (2)기아 퇴 치, (4)형평성 있는 양질의 교육 보장 등의 목표에서 드러나듯이, 부정적인 상태(극 빈, 기아 등)를 완전히 폐지하거나, 추구하는 결과(양질의 초등교육)를 모두가 누릴 수 있게 하는 방식으로, 목표와 세부목표가 보편적으로 적용되어 그 누구도 소외되 지 않도록 하였다. 빈곤 감소를 측정할 때 총계나 평균 수준의 진보 이외에 젠더, 소 득, 지역, 인종·민족 등 주요 차별요인에 따라 데이터를 수집해 발전의 혜택을 누리 는 데 소외·배제가 없도록 적극적 조치를 취할 수 있어야 한다는 것이 인권 분야 전 문가들이 지속적으로 강조해 온 것이다. 아울러 극빈이나 기아는 적절한 생활수준에 대한 권리의 본질적인 최저선(minimum essential level)을 누릴 수 없는 상태로, 국 제인권법 하 국가의 최소핵심의무를 위반하는 것이며(UN Committee on Economic, Social and Cultural Rights, 1990, para. 10). 평등 증진을 독자적인 발전목표로 설정함과 동시에, 모든 다른 목표들에도 반영되도록 하는 것은 유엔 시스템 타스크 팀(2012b, p.6)의 권고와도 일치한다. 
Post-2015 지속가능 발전 목표의 최종안은 2015년 9월 제70차 유엔총회에서 채택 될 예정이다. 이를 위해 2015년 1월부터 7월까지 목표 및 세부목표, 이를 이행하기 위한 수단 및 글로벌 파트너십, 후속 조치 및 평가에 대한 정부 간 협상이 실시된다. 반기문 유엔사무총장은 2014년 12월 '2030년까지 존엄을 향한 길: 빈곤퇴치, 모두의 삶의 전환, 지구보호'라는 제목의 Post-2015 의제에 관한 종합보고서를 발표해, 지 난 3 년 여 간의 논의를 종합하고 향후 논의 방향을 제안하였다. 유엔사무총장도 Post-2015 개발의제가 경제, 사회, 문화, 시민, 정치적 권리뿐 아니라 발전권까지 모든 인권을 기본적인 토대로 하면서, 실질적 평등 증진과 지속가능한 발전을 핵심 적인 방향성으로 추구해야 한다는 점을 일관되게 강조한다(UN Secretary General, paras. $65,82,83)$.

제 I장

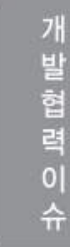

제II장

제피장

제IV장

사무총장은 (1) 존엄(Dignity): 빈곤퇴치 및 불평등 해소, (2) 사람(People): 건강한 삶, 지식 및 여성/아동 포용, (3) 번영(Prosperity) : 강력하고 포용적이며 전환적인 경 제성장, (4) 환경(Planet): 모든 사회와 미래세대를 위한 생태계 보호, (5) 정의 (Justice): 안전하고 평화로운 사회 및 강력한 제도 추구, (6) 파트너십 (Partnership): 지속가능발전을 위한 글로벌 연대 촉진을 Post-2015 개발의제 설정 을 위한 6가지 필수 요소로 제안하였다(2014, paras. 66-86). 첫 번째 요소인 존엄 (Dignity)이라는 요소는 빈곤과 불평등 심화의 현실을 개선하는 것이 이 시대의 핵심 적인 과제임을 상기시키며, 성평등의 증진, 불균등한 기회로 이어질 수 있는 소득불 평등 완화의 중요성을 강조한다. 또한 여성, 청년, 소수자의 목소리를 수용하고, 충 분한 정보 하에 선주민들로부터 사전 동의를 받는 과정을 추구하고, 장애인, 노인, 청소년 및 청년의 참여를 가로막는 요인을 제거하고, 빈곤층의 역량을 강화하고, 이 주민, 난민, 유민 등이 소외되지 않아야 함을 역설한다. 두 번째 요소인 사람 (People)이라는 요소 하에서는 건강, 교육, 식수 위생 등 인간개발 모든 영역에서 보 편적 접근의 보장, 여성에 대한 폭력 근절, 토지와 자산 등 생계수단에 대한 여성의 동등한 접근이 새로운 개발의제에 반영되어야 함을 강조하며, 이는 인권의 존중 차 원에서도 필요한 것임을 재확인한다. 세 번째 번영(Prosperity)이라는 요소는 모든 사람들이 괜찮은 일자리, 생계수단에 접근해 충분한 소득을 유지할 수 있는 포용적 성장의 추구를 뜻한다. 평등의 증진은 소외된 사람들이 의사결정에 더 의미 있게 참 여할 수 있는 공적 제도와 민주적 과정의 강화, 차별과 불평등에 대한 구제수단의 
마련을 통해 가능하다. 이런 점에서, 다섯 번째 정의(Justice)라는 요소가 포함하는 공정한 사법 접근권, 민주적 거버넌스, 시민의 안전, 표현의 자유, 집회결사의 자유, 정보접근권의 보장은 그 자체로 인권으로서 요구될 뿐 아니라, 불평등의 완화를 위 해서도 필수적이다. 현 세대와 미래 시대 간의 평등 증진 차원에서 환경이라는 요소, 국가 간 불평등의 해소와 국제연대가 사회 불평등의 완화를 위해 필수적이라는 점에 서 글로벌 파트너십이라는 요소의 연관성도 충분히 공유되어야 할 것이다.

Post-2015 글로벌 개발의제가 인권적 가치에 바탕을 두고 빈곤 감소와 평등 증진 을 추구해야 함은 공개 작업반의 지속가능 발전목표(안)과 유엔사무총장의 종합보고 서 모두에서 잘 각인되어 있다. 이러한 가치와 목적을 실현하기 위해, 다양한 기관들 이 연구하고 제안한 정책방안들도 비교적 잘 반영되어 있는 편이다. 이제 남은 과제 는 향후 전개될 정부 간 협상에서 이러한 내용들이 약화되지 않도록 하는 것과 협상 결과 9 월에 채택되는 지속가능발전 목표 $\mathrm{SDG}$ )가 제대로 실행되도록 평가 시스템을 제대로 갖추는 것이 될 것이다.

\section{나가며}

사회의 불평등이 국내, 국제적 차원 모두에서 심각한 수준임은 주지의 사실이다. 심각한 사회 불평등은 사람들이 교육권, 건강권, 주거권, 적절한 생활수준에 대한 권 리를 동등하게 향유하지 못하고 있음을 의미하며, 공적 제도 내 의사결정 과정에서 빈곤층 및 사회적 약자들의 발언권이 약함을 나타낸다. 지속적인 불평등은 부유한 계층의 자녀와 그렇지 않은 계층의 자녀들 사이의 불공정한 현재와 미래를 고착화시 킬 위험성이 높고, 이는 사회 내 차별적 규범과 관행, 불관용, 갈등을 증폭시키는 요 인이 된다. 사람들 사이의 소득과 삶의 질의 간극을 더 벌어지게 둘 것인가, 아니면 불평등의 덫을 해체하고 빈곤이 대물림되는 사회의 패턴을 바꿀 수 있을 것인가, 그 기로에서 Post-2015 개발의제에 대한 기대가 높다. 최종안이 채택되는 2015년 9월 까지 이어질 정부 간 협상에서 한국 정부를 비롯한 각국의 정부 대표들은 불평등 해 소라는 인류의 시대적 과제의 중요성이 약화되는 일이 없도록 해야 할 것이다. $\mathrm{OECD}$ 국가들을 비롯한 공여국들은 최빈국을 포함한 개발도상국들이 인권, 평등, 지 속가능한 환경을 지향점으로 빈곤 감소와 사회 발전을 진전시켜 나가는 데 공적개발 
원조가 효과적으로 기여할 수 있도록 해야 할 것이다. 한편 유념해야 할 것은 향후 채택될 Post-2015 지속가능발전목표는 개발도상국에만 해당되는 것이 아니라 모든 국가들이 각국의 상황에 맞게 실천해야 할 보편적 목표라는 점이다(UN Secretary General, 2014, para. 84). '누구도 소외되지 않는 사회’를 지향하는 Post-2015 개 발의제의 비전은 양질의 일자리를 창출하는 포용적 경제정책, 교육·보건·주거 부문의 공공성의 강화, 보편적 사회보장의 확대, 조세제도의 누진성 강화, 차별적 제도와 관 행의 타파를 현실의 구체적인 행동으로 만들어내는 각국 정부와 국제사회의 정치적 의지에 달려 있다.

\section{제 I장}

개
발
협
력
이
슈

제I장

제III장

제IV장 


\section{참고문헌}

\section{- 국내문헌}

경제·사회·문화적 권리에 관한 국제규약(1966)

모든 형태의 인종차별철폐에 관한 국제협약(1966)

발전권선언(1986)

변영학, '금융자유화와 불평등의 국제정치경제: 세계 44 개국의 통계분석, 1980 2000’, 『한국정치연구』 제 22 집 제 2 호, $227-250$

세계인권선언(1948)

시민·정치적 권리에 관한 국제규약(1966)

여성에 대한 모든 형태의 차별철폐에 관한 국제협약(1979)

이주영(2013) '자선을 넘어 지구적 정의의 추구-국제개발에 대한 인권적 접근 의 배경과 의의', 『국제개발협력연구』 제 5 권제 2 호: $97-129$.

이주영 외(2014) '공적개발원조 정책의 현황 및 인권적 개선방안 연구' 2014 년 도 국가인권위원회 연구용역 보고서.

장애인권리협약(2006)

\section{- 국외문헌}

ADB(2012) 'Asian Development Outlook: Confronting Rising Inequality in Asia', Manila: Asian Development Bank.

Berg, A., and J.D. Ostry(2011) 'Inequality and Unsustainable Growth:

Two Sides of the Same Coin?' IMF Staff Discussion Note

11/08. Washington, D.C.: International Monetary Fund.

Dworkin, R.(1981a) 'What is Equality? Part 1: Equality of Welfare',

Philosophy and Public Affairs, Vol.10.

Dworkin, R.(1981b) 'What is Equality? Part 2: Equality of Resources',

Philosophy and Public Affairs, Vol.10.

Fredman, S.(2014) 'Substantive Equality Revisited', University of

Oxford Legal Research Paper Series

〈http://ssrn.com/abstract=2510287〉 최종 접속 2015.1.22. 
IMF(2014a), 'IMF Policy Paper: Fiscal Policy and Income Inequality', Washington D.C.: International Monetary Fund.

IMF(2014b) 'Redistribution, Inequality, and Growth', Washington D.C.: International Monetary Fund.

Kabeer, N. (2010) 'Can the MDGs Provide a Pathway to Social Justice? The Challenges of Intersecting Inequalities', Brighton and New York: Institute of Development Studies and MDG Achievement Fund.

Melamed, C. and E. Samman(2013) 'Equity, Inequality and Human Development in A Post-2015 Framework', New York: UN.

Oxfam(2015) 'Wealth: Having It All and Wanting More', Oxford: Oxfam, http://policy-practice. oxfam.org. uk/publications/wealth-h aving-it-all-and-wanting-more-338125(2015년 1월 21일 최종 접속)

Rawls, J.,(1971) 『A Theory of Justice』, Messachusetts: Harvard University Press.

Roemer, J.(1998) 『Equality of Opportunity』, Messachusetts: Harvard University Press.

Sen, A. K.,(1992) 『Inequality Reexamined』, Messachusetts: Harvard University Press.

Stewart, F.(2008) ${ }^{『}$ Horizontal Inequalities and Conflict: Understanding Violence in Multiethnic Societies』, Palgrave, London.

Stiglitz, J.(2011) 『The Price of Inequality: How Today's Divided Society Endangers Our Future』, W.W. Norton \& Co., New York.

UN(2012a) 'System Task Team on the Post-2015 UN Development Agenda, Addressing Inequalities: The Heart of the Post-2015 Agenda and the Future We Want for All'.

UN(2012b) 'System Task Team on the Post-2015 UN Development Agenda, Towards Freedom from Fear and Want: Human Rights in the Post-2015 Agenda'. 
UN CCPR: Human Rights Committee(1989) 'General Comment No. 18: Non-Discrimination'.

UN CESCR: Committee on Economic, Social and Cultural Rights(1990)

'General Comment No. 3 The Nature of States Parties' Obligations(Art. 2, Para. 1, of the Covenant)'.

UN CESCR: Committee on Economic, Social and Cultural Rights(2009)

'General Comment No. 20: Non-Discrimination'.

UN Department of Economic and Social Affairs(2013) 'Inequality

Matters - Report of the World Social Situations 2013', New York: UN.

UN High-Level Panel of Eminent Persons on the Post-2015 Development Agenda(2013) 'A New Global Partnership: Eradicate Poverty and Transform Economics Through Sustainable Development', New York: UN.

UN Open Working Group of the General Assembly on Sustainable Development Goals(2014) 'Proposal for Sustainable Development Goals', UN Doc. A/68/970.

UN Secretary General(2013) 'A Life of Dignity for All: Accelerating Progress towards the Millennium Development Goals and Advancing the United Nations Development Agenda Beyond 2015', UN Doc. A/68/202, New York: UN.

UN Secretary General(2014) 'The Road to Dignity by 2030: Ending Poverty, Transforming All Lives and Protecting the Planet': Synthesis Report of the Secretary-General On the Post 2015 Agenda, New York: UN.

UN System Task Team on the Post-2015 UN Development Agenda(2012a) 'Addressing Ineqaulities: The Heart of the Post-2015 Agenda and the Future We Want for All'.

UN System Task Team on the Post-2015 UN Development Agenda(2012b) 'Towards Freedom from Fear and Want: Human Rights in the Post-2015 Agenda'. 
UNDP(2013) 'Humanity Divided: Confronting Inequality in Developing Countries', UNDP, New York.

UNRISD(2010) Combating Poverty and Inequality: Structural Change, Social Policy and Politics, Geneva: UNRISD.

World Bank(2006) 'World Development Report 2006: Equity and Development', Washington D.C.: World Bank.

World Economic Forum(2014) 'Global Risks Report 2014’, Geneva: WEF.

제 I장

\begin{tabular}{|l} 
개 \\
발 \\
협 \\
력 \\
이 \\
슈 \\
\hline 제II장 \\
\hline 제피장 \\
\hline 제IV장
\end{tabular}

